\title{
Ismail Noor - Najib Razak: A Sense of Mission, with a Foreword by Datuk Seri Dr Rais Yatim
}

(Batu Caves, Selangor: Thinker's Library, 2009). xxiii+186 pp. ISBN: 978-967-69-0771-4. RM70.00

\section{Abdul Karim Abdullah (alias Leslie Terebessy) International Institute of Advanced Islamic Studies}

“The purpose of this book is to depict Dato' Seri Mohd Najib Tun Razak as the natural successor of Tun Abdul Razak Hussein in terms of the son extending the legacy of his father [...]", writes Ismail Noor in his Najib Razak: A Sense of Mission (p. xxi). Information, Communications and Culture Minister, Datuk Seri Dr Rais Yatim contributed the foreword. The book, at 186 pages, spans 33 years of public life - at both state and federal level - of Dato' Seri Mohd Najib, the current Prime Minister of Malaysia, and highlights his roles as leader, administrator, manager and politician.

The book is introduced on page xvi with a well-known verse from the Qur'ān (49:13):

O mankind! We have created you from a [single] pair of a male and a female, and have made you into nations and tribes, that you may know one another (not that you may despise each other). Verily the noblest of you, in the sight of God, is the best in conduct $[\ldots]$.

Each of the book's ten chapters - illustrated with photographs - highlights a particular stage of the Prime Minister's career. Recollections of the past mingle with glimpses of the present. The chapters conclude with a wise saying by a sage from a different civilisation, reflecting Malaysia's multi-cultural makeup. The book contains an extensive bibliography and index.

Chapter one makes clear that the challenges facing the current Prime Minister are no less daunting than those that had faced his father. The elder Razak's greatest challenge was to re-establish social order and safeguard inter-ethnic harmony in the aftermath of the racial riots of 13 May 1969. The younger Najib's tenure as the Chief Minister of Pahang is recounted in chapter two. Appointed to this post at a young age, he learned to liaise both with state royalty as well as with the national leadership.

Chapter three highlights strategies to overcome the current financial and economic crisis, and explains the stimulus packages launched to spur economic activity. One of Malaysia's priorities is reducing unemployment; this is to be accomplished primarily by increasing the size of the service sector. Liberalisation in key subsectors of the economy, including finance, health, tourism, transport, computers and rental/leasing 
services, has also been scheduled to take place. Creating a high-income economy is another priority.

The fourth chapter outlines Najib's contributions to Felda (Federal Land Development Authority), which aims to be a globally integrated and diversified multi-crop agro-business transnational corporation. Felda has played a prominent role in improving the quality of life of the rural poor. While working as a lecturer at USIM, University Sains Islam Malaysia, the present writer has interacted with a number of university students from the Felda settlements. The students, young men and women, displayed character, discipline, piety, and a keen eagerness to learn.

Najib's stint as minister of education is summed up in chapter five. Among the initiatives undertaken during his tenure was the establishment of the National Higher Education Fund (PTPN).

The prime minister's tenure as Minister of Defence is detailed in chapter six. The Armed Forces underwent much restructuring during this period. A number of peace missions to various conflict zones around the world were launched during this time.

The implementation of the National Service programme is explained in chapter seven. The purpose of the programme is to foster patriotism, camaraderie, and discipline among the younger generation. The emphasis is broadly on national integration. A number of measures have been implemented to improve the programme since its inception.

Chapter eight outlines the Prime Minister's agenda, as encapsulated in the 1 Malaysia concept. In addition to calling for national unity, 1Malaysia aims to make education accessible to all, as well as affordable, and to provide a better quality of life for Malaysians. To achieve this, the Prime Minister introduced key performance indicators (KPIs) for measuring progress in what he termed Key Results Areas (KRAs). These include crime prevention, improved transportation, reducing corruption, and providing better infrastructure (p. 124). Chapter nine gives an account of Najib's loyalty to party.

The last chapter provides an overview of the first 100 days in office. The liberalisation of some subsectors in the economy should stimulate foreign direct investment, affected somewhat by the currency controls imposed during the economic crisis of 1998.

Overall, the book strikes a positive note, while providing a bird's eye view of the immediate challenges faced by Malaysia today. As the Prime Minister stated, "We must reach out to all parts of Malaysia [...] to all our diverse communities. In our national discourse and in pursuing our national agenda, we must never leave anyone behind" (p. 190).

As of this writing, the current Prime Minister is still within the first year of his office, much of which was also preoccupied by responses to the global financial crisis and the incessant challenges posed by the multi-religious and multi-ethnic 
makeup of Malaysia that engage all Malaysian leaders. These issues have taken a more cogent turn since the March 2008 general elections and the transfer of leadership from Tun Abdullah Badawi to the present incumbent. Time will tell how he fares, but - in spite of the inter-ethnic disturbances of January 2010 - early indicators seem to promise positive changes and a consistent pattern of progressive leadership for Malaysia under Prime Minister Najib Razak.

\section{Hans Küng - Islam: Past, Present and Future}

Trans. John Bowden (Oxford: Oneworld Publications, 2008; reprint paperback 2009). xxx+767 pp. ISBN: 978-1-85168-612-4. US\$29.95 [German original: Der Islam: Geschichte, Gegenwart, Zukunft (Munich: Piper Verlag, 2004)]

\section{Karim D. Crow International Institute of Advanced Islamic Studies}

The historian-theologian Hans Küng is best known today for his passionate pursuit of inter-religious dialogue and understanding within a global perspective. Since the 1960s he was professor of Ecumenical Theology at the Eberhard-Karls-Universität of Tübingen in Germany and Emeritus Professor there from 1996. This dissident Swiss Catholic priest is a controversial theologian and prolific author in the inter-faith industry.

Since 1995, his primary occupation has been President of the Foundation for a Global Ethic ${ }^{1}$ (Stiftung Weltethos). He described what world religions share in common, not what separates them, and compiled a minimal code of moral rules everyone might possibly accept. From 2001 onwards, the exhibition "World Religions - Universal Peace - Global Ethic", conceived by Stiftung Weltethos, has been displayed around the world.

Islam completes his trilogy on "The Religious Situation of Our Time", treating the three monotheistic religions of Southwest Asian provenance (Küng employs the expression 'Near Eastern', a Eurocentric designation). The first two volumes were Judaism: Between Yesterday and Tomorrow (1991; English trans. New York: Crossroad, 1992), and Christianity: Its Essence and History (1994; English trans. 1995). In the course of his project, Küng made long filming trips around the world for the television series Spurensuche (aired in Germany in 2000), which then appeared as an illustrated volume and a DVD. ${ }^{2}$ All these remarkable efforts by Küng are the fruit of extensive research conducted between 1989 and 1997, forming the basis for his life project: 'No World Peace without Religious Peace'.

His is a massive scholarly undertaking whose successful completion should be a cause for gratitude and relief. Concerning the structure of this trilogy, Küng states: "The view expressed in this book is the end-product of a long course of 